\title{
Oxybutynin and tolterodine for treatment of neurogenic detrusor overactivity: a pharmacoeconomic evaluation in the Brazilian context
}

\author{
Rodrigo Silva Suguino², Gisele Martins ${ }^{1, *}$, Brunna Carvalho Viana Campos ${ }^{3}$, Raylayne Ferreira \\ Bessa $^{4}$, Démerson André Polli ${ }^{5}$ Mani Indiana Funez ${ }^{3}$, Cris Renata Grou Volpe ${ }^{3}$ \\ ${ }^{1}$ Department of Nursing, Faculty of Health Sciences, University of Brasilia, ${ }^{2}$ Department of Pharmaceutical Sciences, \\ Faculty of Ceilândia, University of Brasilia, ${ }^{3}$ Department of Nursing, Faculty of Ceilândia, University of Brasilia, \\ ${ }^{4}$ Department of Public Health, Faculty of Ceilândia, University of Brasilia, ${ }^{5}$ Department of Statistics, \\ Institute of Exact Sciences, University of Brasilia
}

\begin{abstract}
Antimuscarinic agents are the first-line choice for the treatment of neurogenic detrusor overactivity (NDO). The currently available antimuscarinic drugs have been widely studied in patients presenting idiopathic detrusor overactivity; however, investigations evaluating the effects of these drugs on NDO are scant, particularly with regard to cost-effectiveness analyses. A pharmacoeconomic evaluation was performed to compare the costs and effectiveness of oxybutynin and tolterodine in two different formulations, extended (ER) and immediate-release (IR), for the treatment of NDO (based on Brazilian maximal consumer price index). A systematic review of literature was conducted in order to obtain significant clinical and urodynamic data (based on expert opinion), concerning the effects of these drugs in the neurogenic population. Furthermore, a pharmacoeconomic evaluation was performed and costs involved were calculated based on percentage effectiveness obtained for the timeframes of one month and of one year. The best cost-effectiveness ratio (CER) was observed with oxybutynin IR for the urodynamic parameters. In terms of clinical parameters, oxybutynin IR and ER showed the best CER. Based on the key urological parameters analyzed, oxybutynin IR was considered the most cost-effective antimuscarinic agent.
\end{abstract}

Uniterms: Urinary Bladder Neurogenic. Muscarinic Antagonists. Pharmaceutical economy.

A terapia antimuscarínica é vista como primeira escolha para o tratamento da hiperatividade detrusora de origem neurológica (HDON). No entanto, a maioria dos antimuscarínicos existentes é amplamente estudada em pacientes portadores de hiperatividade detrusora idiopática. Assim, existe escassez de pesquisas que avaliam esses fármacos na problemática da HDON, principalmente em termos de estudos de custo-efetividade. Diante isso, um estudo farmacoeconômico foi realizado (baseado no índice de preço máximo ao consumidor) para comparar os custos e a efetividade da oxibutinina e da tolterodina, em duas diferentes formulações, cápsulas de liberação imediata (LI) e controlada (LC), para o tratamento da HDON. Uma revisão sistemática da literatura foi conduzida para obtenção de dados urodinâmicos e clínicos relevantes (baseado em opinião de especialistas), quanto aos efeitos desses fármacos em pacientes com distúrbios urológicos de origem neurológica. Após essa etapa, um estudo farmacoeconômico foi conduzido e os custos envolvidos foram calculados sobre cada percentual de efetividade obtido, num horizonte temporal de 1 mês e 1 ano. A melhor razão de custo-efetividade (RCE) quanto aos parâmetros urodinâmicos foi obtida com uso de oxibutinina LI. Quantos aos parâmetros clínicos, oxibutinina LI e LC tiveram as melhores RCE. Baseando-se nos principais parâmetros urológicos analisados, oxibutinina LI foi considerada o antimuscarínico mais custo-efetivo.

Unitermos: Bexiga urinária neurogênica. Antagonistas muscarínicos. Economia Farmacêutica.

\footnotetext{
*Correspondence: G. Martins. Faculdade de Ciências da Saúde, Departamento de Enfermagem, Universidade de Brasília, Campus Universitário Darcy Ribeiro, 70910-900 - Brasília - DF, Brazil. E-mails: martinsgise@gmail.com; gmartins@unb.br
} 


\section{INTRODUCTION}

Neurogenic detrusor overactivity (NDO) is related to neurogenic bladder (NB) and generally associated to traumatic medullary damage or neurological disease. NB can stem from damage above the medulla level such as in strokes, tumors and dementia or may be secondary to spinal cord medulla lesions such as in cases of traumatic spinal cord injury, multiple sclerosis, intervertebral disc herniation and inflammatory lesions affecting sites of micturition control (Tanagho, Bella, Lue, 2010).

The term NDO refers to neurological damage caused by trauma or disease which interferes directly with micturition. Affected patients present with urinary incontinence, urgency incontinence, frequency, residual urine or urinary retention. If not treated effectively, patients with NB can develop upper urinary tract infections which can be recurrent and lead to renal failure. Another aggravating problem of NB is its negative impact on patients' quality of life, leading to low self-esteem, and loss of independence, particularly among the elderly population (Chancellor, Anderson, Boone, 2006).

Neurophysiology of micturition is associated with a complex of autonomic and somatic nervous system innervations, which can be divided into afferent and efferent pathways. Afferent paths are composed of receptors originating in the muscle wall and the mucosa of the detrusor muscle, where the signal originates. These signals travel to the dorsal ganglions and the sacral medulla. The pontine center for micturition is the final site where the afferent signals are perceived sensorially. The efferent system for micturition emerges from the pontine center causing excitation via the sacral parasympathetic pathways to contract the detrusor and the sacral somatic pathways to relax the sphincter. Other organs are also involved in micturition control including the cerebellum, cerebral cortex, thalamus and hypothalamus, which exert control over the pontine micturition center (Kennelly, DeVoe, 2008).

Conservative therapy with antimuscarinic drugs is the first choice for treatment of patients with NDO. Two of the leading antimuscarinic drugs available in the market are Oxybutynin and Tolterodine which, as antimuscarinic agents, have a direct antispasmodic effect on smooth muscle receptors. Thus, these drugs inhibit the muscarinic action of acetylcholine (released from the parasympathetic terminals) on the smooth muscle of the detrusor (Woodward, 2004).

Oxybutynin was the first antimuscarinic drug to be approved for the management of detrusor overactivity secondary to neurogenic bladder. It was developed by Majewski and patented in 1965. Ten years later (1975), it was approved by the Food and Drug Administration (FDA) of the United States for treatment of uncontrolled neurogenic bladder reflexes as well as for treatment of nocturnal enuresis in patients over five years of age. This advance was possible due to the fact that the first trials of the main active ingredient were conducted using cystometrography in a patient with $\mathrm{NB}$, a urodynamic technique which allowed the measurement of internal urinary bladder pressure.

In 1980, oxybutynin was shown to be effective not only for individuals with NB but also for patients who had idiopathic detrusor overactivity or of unknown etiology. Mosley et al (1980) carried out a randomized double blind study with oxybutynin in 30 patients who had bladder instability, whose results showed a subjective improvement in symptoms. This led to the approval in 1992 of Oxybutynin by the FDA for detrusor instability (Dionne, Ingber, 2006).

A major drawback of oxybutynin use is the high level of side effects. The low selectivity in specific muscarinic receptors of urinary function, affects other physiological systems causing dry mouth, constipation and heat intolerance in around one third of patients. These side effects are the main reason for noncompliance with therapy. Another reason for non-adherence to therapy is the need for a three times daily dose. A sustained or extended release oxybutynin preparation was developed in order to overcome these issues (Aslan, Kogan, 2002). Although oxybutynin has collateral effects (particularly immediate release form), it remains the most commonly used drug in Brazil due to its efficacy and low cost (Palma, 2007).

Another antimuscarinic drug developed in the mid1990s was tolterodine, acclaimed as a muscarinic antagonist which was more selective for bladder receptors. Overall, this medication was better accepted and tolerated by patients in comparison to oxybutynin (Woodward, 2004).

Nevertheless, in the Brazilian context, the costs involved in treatment with tolterodine for NDO are much higher than those with the use of oxybutynin, especially considering the price made available by the National Agency of Health Safety (ANVISA). The literature reinforces the fact that, while the monthly cost of tolterodine is higher, it is better tolerated in terms of undesirable side effects. This economic aspect should be considered as a selection criteria and taken into account for each patient (Palma, 2007).

The current study entailed a pharmacoeconomic analysis of the cost-benefit type, whose objective was to determine and compare the cost-effectiveness ratio of oxybutynin and tolterodine in their two formulations, namely capsules offering timed, controlled release (CR) and immediate release (IR), for the treatment of NDO. 
The cost calculations in this study were based on the 2009 maximum consumer price index compiled by the ANVISA for the year 2009, and patients' perspective.

\section{METHODOLOGY}

A systematic literature review was done using the following databases: Pub Med, Cochrane Library, CINAHL, Embase, MEDLINE, Web of Science, Current Controlled Trials, Evidence-NHS, Centre for Reviews and Dissemination (CRD York), INAHTA, LILACS, SciELO and IBECS. The review also included content from journals and those studies in the references of relevant articles which met the inclusion criteria. These searches were performed in each database by four independent reviewers.

No time limit was defined for publication date and only articles written in English and Spanish were included as no articles were found written in Portuguese. Retrieval was based on a total of 578 descriptive combinations including Bladder, Neurogenic; Cholinergic antagonists; Muscarinic Antagonists; Oxybutynin; Tolterodine and Urinary Bladder, Overactive.

The selected studies met the following inclusion criteria:

- Studies which included only NDO patients;

- Use of oxybutynin and tolterodine by oral route;

- Details given in the study on dose regimen/duration of treatment;

- $\quad$ Studies which used the two antimuscarinic agents, both prospective or retrospective;

- Inclusion of clinical and urodynamic information, showing effectiveness of the antimuscarinic therapy used.

The exclusion criteria applied were as follows:

- Integrated or narrative review articles, and

- Other antimuscarinic formulations used (intrabladder, transdermal).

A total of 29 studies were found meeting the inclusion criteria, only 22 of which were included in the final sample for data extraction after evaluation. Among the principal reasons for exclusion of the initial 7 articles were the following problems:

- Clinical and urodynamic parameters were not individually separated for each antimuscarinic drug studied, and

- Absence of effectiveness parameters both pre and post treatment.

It is important to highlight that for a pharmacoeconomic study, the average price paid by the consumer in the Brazilian market, was calculated (based on mean national price set by ANVISA in 2009) for the oral formulations (pills and capsules) of the two antimuscarinic drugs oxybutynin and tolterodine.

The following urodynamic parameters were used:

- Increase in cystometric capacity $\geq 10 \%$;

- Decrease in detrusor pressure $\leq 40 \mathrm{cmH}_{2} \mathrm{O}$;

- Increase in bladder compliance.

The following clinical parameters were used:

- Increase in urinary volume eliminated in each urinary effort or catheterization

- Mean number of episodes of urgency with incontinence and/or urge-incontinence.

Studies used to determine the efficacy of the medications in the pediatric population were: 1.Mahanta, K. et al. 2.Franco, I et al. 3.Cartwright, P. C. et al. 4.Goessl, C. et al. 5.Christoph, F. et al. 6.Reddy, P. P. et al. 7.Youdim, K. et al. 8.Madesbacher, H. et al. 9.Ferrara, P. et al. 10. Pannek, J. et al. 11.Ellsworth, P. I. et al. 11.Goessl, C. et al.

The selected studies which investigated the efficacy of these drugs in the adult population included: A.1.Bennett, N. et al. A.2.Kawabe, K. et al. A.3.Ethans, K. D. et al. A.4.Fader, M. et al. A.5.Horstmann, M. et al. A.6.Brooks, M. E. et al. A.7.Gajewski, J. B. et al. A.8.Stohrer, M. et al. A.9.Madersbacher, H. et al. A.10. Van Kerrebroeck, P. E. V. A. et al.

In order to calculate the daily, monthly and annual cost of each medication used, we calculated the average price according to the data available on pricing from the ANVISA site for 2009. In addition, it was necessary to calculate the weighted mean price of each pack of these antimuscarinic drugs, sold by all the pharmaceutical companies which commercialize these products, according to the Tax on the Circulation of Goods and Services (ICMS) of each Brazilian State. The cost of each medication was then defined in terms of Reais per milligram $(\mathrm{R} \$ / \mathrm{mg})$.

The efficacy/effectiveness of the selected antimuscarinic drugs was stratified in terms of clinical and urodynamic parameters. Using values suggested by the literature search and a consensus opinion on this subject by specialists, the following urodynamic parameters of effectiveness after intervention were the following: $\mathrm{a} \geq 10 \%$ increase in cystometric capacity measured, detrusor pressure reduced to $\leq 40 \mathrm{cmH}_{2} \mathrm{O}$, and augmented bladder compliance. In terms of the clinical parameters of effectiveness, the following were considered: increase in urinary volume excreted by natural means or by catheter, in a period of 24 hours, and a decrease in the average number of incontinence episodes (urgency or urge-incontinence) over a 24-hour period.

The most cost-effective medication was obtained by calculations based on monthly cost divided by the parameter measured in percentages and natural units. This method allowed calculation of the cost of a $1 \%$ increase or 
decrease and one natural unit increase or decrease, for each investigated parameter. It is worth emphasizing that the average efficacy was calculated (along with the respective standard deviation) for all analyzed parameters, based on the average dose of each antimuscarinic drug, according to the doses adopted in the studies selected in the systematic literature search.

Precision of all calculations was to four decimal places. These were then reduced to two decimal places for ease of presentation of results.

\section{RESULTS}

The mean number of milligrams in each dose of the antimuscarinic studies and the corresponding average price is shown in Table I. The national average price of oxybutynin CR in 2009 was $\mathrm{R} \$ 0.2295 / \mathrm{mg}$ and $\mathrm{R} \$ 2.5472$ for tolterodine CR. The average price for IR oxybutynin was $\mathrm{R} \$ 0.1269 / \mathrm{mg}$ versus $\mathrm{R} \$ 2.0458$ for IR Tolterodine.

Tables II and III give details regarding efficacy of each antimuscarinic drug, separately for pediatric and adult patients, according to the clinical data and urodynamic parameters analyzed.

It can be seen that tolterodine CR yielded better results than oxybutynin $\mathrm{CR}$ across all the urodynamic parameters evaluated, based on percentage values for both the pediatric and adult populations. For the IR formulation, tolterodine IR showed better performance in percentage terms than oxybutynin IR only for the increase in cystometric capacity parameter in the pediatric population. For the rest of the parameters measured, in both pediatric and adult populations, oxybutynin gave better results compared to tolterodine IR, suggesting it was more effective.

On clinical parameter analysis, the greatest volume increase in urinary volume eliminated with urination or by catheter use, was found with tolterodine $\mathrm{CR}$, given the better percentage results obtained in comparison to oxybutynin CR. Comparing immediate release formulations
(IR), tolterodine produced better results than oxybutynin in the pediatric group; but the reverse was true for the adult group in which oxybutynin had a superior result for the same parameter.

With regard to reduction in average number of incontinence episodes, tolterodine had better percentage results than oxybutynin only in the pediatric population and only for the IR formulation. No studies described this parameter for oxybutynin IR. Concerning the other populations and formulations, oxybutynin had the best results.

Tables IV and V show daily dose in milligrams calculated for each antimuscarinic drug, according to each selected study; the cost benefit ratio of each antimuscarinic drug is separated into urodynamic and clinical parameters respectively, considering the daily maintenance of the treatment over the time period considered.

The results suggest that Oxybutynin IR is the lowest cost antimuscarinic medication offering the most favorable overall effectiveness in both pediatric and adult populations given its greater efficacy at a lower price for each urodynamic parameter studied. On the other hand, it should be noted that no reports investigating effectiveness parameters for the outcome of reduction in detrusor pressure or increased bladder compliance, associated to the use of tolterodine $\mathrm{CR}$ were available.

In relation to the cost-effectiveness ratios for clinical parameters, the data suggest that oxybutynin IR is the lowest cost antimuscarinic drug and has the lowest price associated with a $1 \%$ increase in volume of urine eliminated by urination or catheter use. Considering the $\mathrm{CR}$ formulation in the adult population, information was available only for tolterodine whose cost was $\mathrm{R} \$ 11.00$.

In summary, regarding the parameter related to reduction in average number of urgency incontinence or urge-incontinence episodes, in the pediatric population, the lowest cost and most effective muscarinic drug was oxybutynin in both CR and IR formulation. Studies were available only for tolterodine IR, whose cost was

TABLE I - Average milligrams in antimuscarinic drug packs studied, according to average consumer price and price per milligram. Brazil, 2009

\begin{tabular}{|c|c|c|c|c|c|c|}
\hline Antimuscarinic Drugs & \multicolumn{3}{|c|}{ Amount per pack (mg) } & $\begin{array}{c}\text { Average (SD) } \\
(\mathrm{mg})\end{array}$ & $\begin{array}{c}\text { APC* } \\
(\mathrm{R} \$)\end{array}$ & $\begin{array}{c}\text { Average Price } \\
(\mathrm{R} \$ / \mathrm{mg})\end{array}$ \\
\hline$\overline{\text { Oxybutynin CR }}$ & \multicolumn{3}{|c|}{300} & $300.00(0.00)$ & 68.86 & $\mathrm{R} \$ 0.2295$ \\
\hline Oxybutynin IR & 100 & 150 & 300 & $183.33(84.98)$ & 27.12 & $\mathrm{R} \$ 0.1269$ \\
\hline Tolterodine CR & \multicolumn{2}{|c|}{56} & 112 & $84.00(28.00)$ & 237.74 & $\mathrm{R} \$ 2.5472$ \\
\hline Tolterodine IR & 28 & 56 & 120 & $68.00(38.51)$ & 161.59 & $\mathrm{R} \$ 2.0458$ \\
\hline
\end{tabular}

(*) APC: Average price to consumer for 2009: Weighted average of all laboratories according to ICMS of each state, according to price list set by ANVISA for 2009. 
TABLE II - Urodynamic parameters of each antimuscarinic drug used in pediatric and adult populations, according to pre and post treatment data, and difference in each medication used. Brazil, 2009

\begin{tabular}{|c|c|c|c|c|c|c|c|c|}
\hline Population & Parameter & $\begin{array}{c}\text { Antimuscarinic } \\
\text { Drug }\end{array}$ & Study & $\mathrm{N}$ & $\begin{array}{c}\text { Mean Pre } \\
(\mathrm{SD})\end{array}$ & $\begin{array}{c}\text { Mean Post } \\
\text { (SD) }\end{array}$ & $\begin{array}{c}\text { Difference in } \\
\text { unit values }\end{array}$ & $\begin{array}{c}\text { Difference } \\
\text { in } \%\end{array}$ \\
\hline \multirow{12}{*}{ Pediatric } & \multirow{4}{*}{$\begin{array}{l}\text { Cystometric } \\
\text { capacity } \\
\text { increased by } \\
\geq 10 \%\end{array}$} & Oxy CR & $2 ; 3$ & 70 & $195.66(2.90)$ & $264.66(9.71)$ & +69.00 & $+35.27 \%$ \\
\hline & & Tolt CR & $1 ; 6 ; 11$ & 64 & $159.16(53.32)$ & $225.32(77.17)$ & +66.16 & $+41.57 \%$ \\
\hline & & Oxy IR & $2 ; 3 ; 8 ; 9 ; 10 ; 12$ & 248 & $186.86(40.70)$ & $267.82(47.86)$ & +80.96 & $+43.33 \%$ \\
\hline & & Tolt IR & $1 ; 4 ; 5 ; 6 ; 11$ & 171 & $124.53(6.93)$ & $184.39(88.14)$ & +59.86 & $+48.07 \%$ \\
\hline & \multirow{4}{*}{$\begin{array}{l}\text { Detrusor } \\
\text { pressure } \\
\text { decreased } \\
\leq 40 \mathrm{cmH}_{2} \mathrm{O}\end{array}$} & Oxy CR & $2 ; 3$ & 70 & $43.23(0.77)$ & $33.59(0.26)$ & -9.64 & $-22.30 \%$ \\
\hline & & Tolt CR & 1 & 25 & $50.00(* * *)$ & $36.80(* * *)$ & -13.20 & $-26.40 \%$ \\
\hline & & Oxy IR & $2 ; 3 ; 9 ; 12$ & 135 & $46.22(2.50)$ & $30.18(2.13)$ & -16.04 & $-34.70 \%$ \\
\hline & & Tolt IR & $1 ; 4 ; 5$ & 67 & $50.17(12.76)$ & $34.83(1.97)$ & -15.34 & $-30.58 \%$ \\
\hline & \multirow{4}{*}{$\begin{array}{l}\text { Bladder } \\
\text { compliance } \\
\text { improved }\end{array}$} & Oxy CR & NR & NR & NR & NR & NR & NR \\
\hline & & Tolt CR & 1 & 25 & $2.28(* * *)$ & $4.43(* * *)$ & +2.15 & $+94.30 \%$ \\
\hline & & Oxy IR & $9 ; 12$ & 108 & $7.38(0.80)$ & $15.70(1.00)$ & +8.32 & $+112.74 \%$ \\
\hline & & Tolt IR & $1 ; 4 ; 5$ & 90 & $10.86(6.59)$ & $12.37(5.90)$ & +1.51 & $+13.90 \%$ \\
\hline \multirow{8}{*}{ Adult } & \multirow{4}{*}{$\begin{array}{l}\text { Cystometric } \\
\text { capacity } \\
\text { increased by } \\
\geq 10 \%\end{array}$} & Oxy CR & NR & NR & NR & NR & NR & NR \\
\hline & & Tolt CR & A. 5 & 11 & $308.00(* * *)$ & $480.00(* * *)$ & +172.00 & $+55.84 \%$ \\
\hline & & Oxy IR & A.4; A.6; A.7; A.8; A.9 & 164 & $184.46(32.26)$ & $300.16(28.20)$ & +115.70 & $+62.72 \%$ \\
\hline & & Tolt IR & A. $3 ;$ A. 10 & 91 & $156.36(39.26)$ & $353.79(205.81)$ & +197.43 & $+126.27 \%$ \\
\hline & \multirow{4}{*}{$\begin{array}{l}\text { Bladder } \\
\text { compliance } \\
\text { increased }\end{array}$} & Oxy CR & NR & NR & NR & NR & NR & NR \\
\hline & & Tolt CR & NR & NR & NR & NR & NR & NR \\
\hline & & Oxy IR & A. $8 ;$ A. 9 & 81 & $17.08(4.93)$ & $55.77(20.22)$ & +38.69 & $+226.52 \%$ \\
\hline & & Tolt IR & A. 10 & 55 & $31.13(13.70)$ & $67.78(6.90)$ & +36.65 & $+117.73 \%$ \\
\hline
\end{tabular}

NR: data not reported in article.

*** Not possible to estimate standard deviation since only one article retrieved, and information was absent. Standard deviations were estimated as variation between means in articles, considering that each patient had a value equal to the corresponding weighted average.

TABLE III - Clinical parameters for each antimuscarinic drug used in pediatric and adult populations, according to pre and post treatment data, and difference in each medication used. Brazil, 2009

\begin{tabular}{|c|c|c|c|c|c|c|c|c|}
\hline Population & Parameter & $\begin{array}{c}\text { Antimuscarinic } \\
\text { Drug }\end{array}$ & Study & $\mathrm{N}$ & $\begin{array}{c}\text { Mean Pre } \\
(\mathrm{SD})\end{array}$ & $\begin{array}{c}\text { Mean Post } \\
\text { (SD) }\end{array}$ & $\begin{array}{c}\text { Difference in } \\
\text { unit values }\end{array}$ & $\begin{array}{c}\text { Difference } \\
\text { in } \%\end{array}$ \\
\hline \multirow{8}{*}{ Pediatric } & \multirow{4}{*}{$\begin{array}{l}\text { Increase in urinary } \\
\text { volume eliminated } \\
\text { by urination or } \\
\text { catheterization }\end{array}$} & Oxy CR & $2 ; 3$ & 70 & $112.65(57.23)$ & $142.57(72.95)$ & +29.92 & $+26.56 \%$ \\
\hline & & Tolt CR & $6 ; 11$ & 39 & $129.88(4.79)$ & $169.73(7.70)$ & +39.85 & $+30.68 \%$ \\
\hline & & Oxy IR & $2 ; 3$ & 27 & $112.52(0.43)$ & $140.26(7.42)$ & +27.4 & $+24.65 \%$ \\
\hline & & Tolt IR & $6 ; 11$ & 123 & $57.20(26.23)$ & $73.78(24.65)$ & +16.58 & $+28.99 \%$ \\
\hline & \multirow{4}{*}{$\begin{array}{l}\text { Decreased number } \\
\text { of episodes of U.I/ I } \\
\text { in } 24 \text { hours }\end{array}$} & Oxy CR & 7 & 12 & $8.50(* * *)$ & $1.80(* * *)$ & -6.70 & $-78.82 \%$ \\
\hline & & Tolt CR & 11 & 33 & $2.40(000)$ & $1.73(0.29)$ & -0.67 & $-27.92 \%$ \\
\hline & & Oxy IR & NR & NR & NR & NR & NR & NR \\
\hline & & Tolt L.IR & 11 & 83 & $4.71(0.45)$ & $3.87(0.52)$ & -0.84 & $-17.83 \%$ \\
\hline \multirow{8}{*}{ Adult } & \multirow{4}{*}{$\begin{array}{l}\text { Increase in urinary } \\
\text { volume eliminated } \\
\text { by urination / } \\
\text { catheterization }\end{array}$} & Oxy CR & NR & NR & NR & NR & NR & NR \\
\hline & & Tolt CR & A. 5 & 11 & $225.00(* * *)$ & $350.00(* * *)$ & +125.0 & $+55.56 \%$ \\
\hline & & Oxy IR & A. $2 ;$ A. 8 & 54 & $179.80(43.26)$ & $215.42(46.02)$ & +35.2 & $+19.81 \%$ \\
\hline & & Tolt IR & A. 10 & 71 & $136.70(5.85)$ & $155.70(11.87)$ & +19.00 & $+13.90 \%$ \\
\hline & \multirow{4}{*}{$\begin{array}{l}\text { Decreased number } \\
\text { of episodes of U.I/I } \\
\text { in } 24 \text { hours }\end{array}$} & Oxy CR & A. 1 & 39 & $4.30(* * *)$ & $1.70(* * *)$ & -2.60 & $-60.47 \%$ \\
\hline & & Tolt CR & NR & NR & NR & NR & NR & NR \\
\hline & & Oxy IR & A. $4 ;$ A. $7 ;$ A. 8 & 121 & $2.33(0.76)$ & $1.28(0, .6)$ & -1.05 & $-45.06 \%$ \\
\hline & & Tolt IR & A. 10 & 71 & $4.83(1.19)$ & $3.28(0.90)$ & -1.55 & $-32.09 \%$ \\
\hline
\end{tabular}

NR: data not reported in article.

*** Not possible to estimate standard deviation since only one article retrieved, and this information was absent. Standard deviations were estimated as variation between means found in articles, considering that each patient had a value equal to the corresponding weighted average. 
TABLE IV - Cost-effectiveness ratios for urodynamic parameters according to \% value and natural unit price, cost of therapy for one month and for one year, among pediatric and adult populations. Brazil, 2009

\begin{tabular}{|c|c|c|c|c|c|c|}
\hline Population & Parameter & Antimuscarinic Drug & $\begin{array}{c}\text { Average dose } \\
(\mathrm{mg} / \mathrm{d})^{*}\end{array}$ & $\begin{array}{c}\text { Increased Price } \\
[1 \% / \text { (natural unit })]^{* *}\end{array}$ & $\begin{array}{c}\text { Price } \\
(1 \mathrm{month})^{* * *}\end{array}$ & $\begin{array}{c}\text { Price } \\
(1 \text { year })^{* * * *}\end{array}$ \\
\hline \multirow{12}{*}{ Pediatric } & \multirow{4}{*}{$\begin{array}{c}\text { Cystometric } \\
\text { capacity increased } \\
\text { by } \geq 10 \%\end{array}$} & Oxybutynin C.L & 12.28 & $2.40 /(1.22)$ & 84.51 & 1014.16 \\
\hline & & Tolterodine C.L & 3.28 & $6.02 /(3.78)$ & 250.26 & 3044.86 \\
\hline & & Oxybutynin I.R & 8.99 & $0.77 /(0.42)$ & 34.14 & 415.33 \\
\hline & & Tolterodine I.R & 2.02 & $2.58 /(2.07)$ & 123.80 & 1506.28 \\
\hline & \multirow{4}{*}{$\begin{array}{l}\text { Detrusor pressure } \\
\quad \text { reduced } \\
\leq 40 \mathrm{cmH}_{2} \mathrm{O}\end{array}$} & Oxybutynin C.L & 12.28 & $3.79 /(8.77)$ & 84.51 & 1014.16 \\
\hline & & Tolterodine C.L & 2.00 & $5.79 /(11.58)$ & 152.83 & 1859.46 \\
\hline & & Oxybutynin I.R & 4.72 & $0.51 /(1.09)$ & 17.97 & 218.64 \\
\hline & & Tolterodine I.R & 2.88 & $5.28 /(10.55)$ & 176.57 & 2148.2 \\
\hline & \multirow{4}{*}{$\begin{array}{l}\text { Bladder } \\
\text { compliance } \\
\text { increased }\end{array}$} & Oxybutynin C.L & NR & NR & NR & NR \\
\hline & & Tolterodine C.L & 2.00 & $1.62 /(71.08)$ & 152.83 & 1859.46 \\
\hline & & Oxybutynin I.R & 3.09 & $0.11 /(1.46)$ & 11.77 & 143.15 \\
\hline & & Tolterodine I.R & 2.71 & $11.98 /(145.86)$ & 166.09 & 2020.75 \\
\hline \multirow{8}{*}{ Adult } & \multirow{4}{*}{$\begin{array}{c}\text { Cystometric } \\
\text { Capacity increased } \\
\text { by } \geq 10 \%\end{array}$} & Oxybutynin C.L & NR & NR & NR & NR \\
\hline & & Tolterodine C.L & 8.00 & $10.95 /(3.55)$ & 611.33 & 7437.82 \\
\hline & & Oxybutynin I.R & 13.26 & $0.81 /(0.44)$ & 50.49 & 614.30 \\
\hline & & Tolterodine I.R & 3.66 & $4.80 /(2.79)$ & 224.75 & 2734.47 \\
\hline & \multirow{4}{*}{$\begin{array}{l}\text { Bladder } \\
\text { compliance } \\
\text { increased }\end{array}$} & Oxybutynin C.L & NR & NR & NR & NR \\
\hline & & Tolterodine C.L & NR & NR & NR & NR \\
\hline & & Oxybutynin I.R & 15.00 & $0.25 /(1.44)$ & 57.11 & 694.78 \\
\hline & & Tolterodine I.R & 4.15 & $2.16 /(6.94)$ & 254.43 & 3095.53 \\
\hline
\end{tabular}

NR: data not reported in article.

Price $=$ in Reais (Brazil).

(*) Average daily dose in studies analyzed. (**) Additional R \$ for every $1 \%$ increase or decrease in parameter, considering difference between post and pre intervention levels. (***)Considering one month as 30 days - price based on mean 2009 price. (****)Considering one year as 365 days - price based on mean 2009 price.

$\mathrm{R} \$ 114.15$ per episode avoided. For the adult population, the lowest cost per reduced episode was found to oxybutynin in both IR and CR formulations, since no studies investigating the comparative costs for tolterodine $\mathrm{CR}$ were available.

\section{DISCUSSION}

The elevated costs of health management, especially those related to pharmaceutical costs to the patient have become a growing concern in public health. In the case of urology, and more specifically, among NDO patients, the costs involved in the diagnosis and treatment of this dysfunction can have a significant financial impact on patients and the health care system. One of the main reasons for this is the need for chronic use of medication and frequent medical consultations as well as exams such as urinary bacterial cultures, urodynamic examinations, ultrasonography as well as expenses with urinary catheters etc. In addition to these costs, indirect and intangible costs must also be considered such as impaired quality of life, caregiver burden (in cases of patients who cannot care for themselves) and loss of professional productivity in the work place.

Another aspect warranting emphasis regarding costs involved in NDO treatment is the lack of information on the average costs of treating NDO with pharmacologic agents. Nevertheless, in the case of bladder overactivity or idiopathic detrusor overactivity, medication costs represent a significant part of the direct treatment costs. In the United States, the cost of a year's treatment with oxybutynin is \$506 dollars while in the UK similar treatment costs $£ 226$ a year. For tolterodine, the US costs are $\$ 1044$ whereas in the UK the cost is $£ 508$ (McGhan, 2001).

The costs in Canada are estimated to be even higher. Direct and indirect costs of urinary incontinence in the 
TABLE V - Cost-effectiveness ratios for clinical parameters by \% value and natural unit price, cost of therapy for one month and for one year, in both pediatric and adult populations. Brazil, 2009

\begin{tabular}{|c|c|c|c|c|c|c|}
\hline Population & Parameter & $\begin{array}{l}\text { Antimuscarinic } \\
\text { Drug }\end{array}$ & $\begin{array}{l}\text { Average dose } \\
(\mathrm{mg} / \mathrm{d})^{*}\end{array}$ & $\begin{array}{c}\text { Price Increase } \\
{\left[1 \% /(\text { natural unit) }]^{* *}\right.}\end{array}$ & $\begin{array}{c}\text { Price } \\
(1 \mathrm{month}) * * *\end{array}$ & $\begin{array}{c}\text { Price } \\
(1 \text { year })^{* * * *}\end{array}$ \\
\hline \multirow{8}{*}{ Pediatric } & \multirow{4}{*}{$\begin{array}{l}\text { Increased Urinary } \\
\text { volume eliminated/ } \\
\text { catheterized }\end{array}$} & Oxybutynin CR & 12.28 & $3.18 /(2.82)$ & 84.51 & 1014.16 \\
\hline & & Tolterodine CR & 4.09 & $10.57 /(8.14)$ & 312.72 & 3804.72 \\
\hline & & Oxybutynin IR & 11.24 & $1.74 /(1.54)$ & 42.78 & 520.45 \\
\hline & & Tolterodine IR & 1.47 & $3.10 /(5.43)$ & 90.01 & 1095.07 \\
\hline & \multirow{4}{*}{$\begin{array}{c}\text { Number of episodes } \\
\text { of U.I } \\
\text { or IU in } 24 \text { hours }\end{array}$} & Oxybutynin CR & 8.88 & $1.04 /(17.42)$ & 61.12 & 743.58 \\
\hline & & Tolterodine CR & 4.00 & $11.00 /(458.47)$ & 305.66 & 3718.91 \\
\hline & & Oxybutynin IR & NR & NR & NR & NR \\
\hline & & Tolterodine IR & 1.56 & $5.38 /(114.15)$ & 95.99 & 1167.85 \\
\hline \multirow{8}{*}{ Adult } & \multirow{4}{*}{$\begin{array}{l}\text { Increased Urinary } \\
\text { volume eliminated/ } \\
\text { catheterized }\end{array}$} & Oxybutynin CR & $\mathrm{NR}$ & NR & NR & NR \\
\hline & & Tolterodine CR & 8.00 & $11.00 /(4.89)$ & 611.33 & 7437.82 \\
\hline & & Oxybutynin IR & 14.50 & $3.02 /(1.60)$ & 55.20 & 671.62 \\
\hline & & Tolterodine IR & 3.66 & $16.17 /(11.83)$ & 224.75 & 2734.47 \\
\hline & \multirow{4}{*}{$\begin{array}{c}\text { Number of episodes } \\
\text { of U.I } \\
\text { or IU in } 24 \text { hours }\end{array}$} & Oxybutynin CR & 19.49 & $2.22 /(51.60)$ & 134.17 & 1632.39 \\
\hline & & Tolterodine CR & NR & NR & NR & NR \\
\hline & & Oxybutynin IR & 12.64 & $1.07 /(45.90)$ & 48.14 & 585.68 \\
\hline & & Tolterodine IR & 3.66 & $7.01 /(145.20)$ & 224.75 & 2734.47 \\
\hline
\end{tabular}

NR: data not reported in article.

Price $=$ in Reais ( Brazilian).

$\left(^{*}\right)$ Average daily dose in studies analyzed. $\left(^{* *}\right)$ Additional R $\$$ for every $1 \%$ increase or decrease in parameter, considering difference between post and pre intervention levels. (***)Considering one month as 30 days - price based on mean 2009 price. (****)Considering one year as 365 days - price based on mean 2009 price.

Canadian population have been estimated at 2.6 billion dollars per year, which is higher than American costs. Considering each drug separately, a year of bladder overactivity treatment with oxybutynin CR costs $\$ 656$ (CAD), $\$ 534$ of which is related directly to drug costs whereas $\$ 688$ (CAD) represents the cost for a year's treatment with tolterodine, of which $\$ 550$ represents direct drug costs (Getsios, et al. 2004).

In the present study, the antimuscarinic drug with the best effectiveness profile and lowest price was oxybutynin. When stratifying by age group or pediatric/adult patients and both clinical and urodynamic parameters, oxybutynin remained the lowest cost with the best performance characteristics.

In Brazil, weighted values for the antimuscarinic drug tolterodine are unfavorable, due to the economic conditions of the Brazilian population, in spite of the fact that tolterodine seems to be associated with better adherence to therapy and to have a tolerability index three times higher than that of oxybutynin (McGhan, 2001).

Based on this assertion, tolterodine has become the second therapeutic option in clinical practice, indicated in oxybutynin-refractory cases. Another important aspect to be considered is that in Brazil, tolterodine is not yet included in the list of Medications Prescribable under Exceptional Circumstances (Componentes de Medicamentos de Dispensação Excepcional: CMDE), also called "high cost" drugs. This is important in that its use as a chronic ongoing therapy would be unaffordable for most of the Brazilian population.

The literature reinforces the fact that tolterodine is better accepted and tolerated. In a study involving Asian patients randomized to receive tolterodine $(\mathrm{n}=112) 2 \mathrm{mg}$ twice a day, or oxybutynin ( $\mathrm{n}=116) 5 \mathrm{mg}$ twice a day, 62 of the 112 patients $(55 \%)$ receiving tolterodine reported 101 events involving side effects whereas 152 episodes of adverse effects were reported by 94 patients $(82 \%)$ in the oxybutynin group. Dry mouth was the most commonly reported side effect, followed by dyspepsia, abdominal pain, and headache (Lee et al. 2002). Another multicentric, double-blind, randomized study in which patients received either $2 \mathrm{mg}$ of tolterodine $(\mathrm{n}=190)$ twice a day or $2.5 \mathrm{mg}$ of oxybutynin $(\mathrm{n}=188)$ twice a day, in order to determine tolerability, showed that $22(12 \%)$ of the tolterodine group dropped out of the study due to adverse effects, compared to $28(15 \%)$ in the oxybutynin group. 
Moreover, 132 (69\%) patients complained of at least one side effect in the tolterodine group, in contrast to 153 undesirable similar side effects reported by the group of 188 individuals on oxybutynin (81\%). Dry mouth was once again the most commonly reported side effect found in 71 out of 190 patients (37\%) in the tolterodine group, and in 114 out of 188 patients $(61 \%)$ in the oxybutynin group (Malone-Lee et al. 2001).

Our results suggest that the two antimuscarinic drugs, oxybutynin and tolterodine, show distinct outcomes as to their effectiveness. In the case of oxybutynin CR, this seems to be clinically relevant. This was especially notable in terms of the number of reduced episodes of incontinence (a highly significant clinical outcome measure for patient satisfaction). This resulted in an effectiveness of around $60 \%$ for both population groups assessed. The pediatric population showed reduced incontinence episodes by an average of 6.7 episodes per day, while the adult group reported an average reduction in incontinence episode of 2.6 per day. .

Analysis of the pertinent literature revealed an increasingly significant number of publications on the subject of bladder overactivity. However, studies addressing antimuscarinic treatment in the NDO patient population were scant and generally classified as based on a low quality of evidence. The major challenge in this area is to conduct studies with better methodological design, with a view to performing a meta-analysis on the resulting information. Thus, given the need for further studies on patients with $\mathrm{NB}$, this preliminary exploratory study was of fundamental importance. Discovery of new technologies, especially low cost solutions, constitutes one of the most important factors for successful treatment of NDO, particularly with regard to the use of antimuscarinic medications.

\section{CONCLUSION}

This study found that in 2009, oxybutynin IR was the cheapest and most effective medication for the treatment of NDO, based on clinical and urodynamic parameters, in both the pediatric and adult populations in Brazil.

\section{STUDY LIMITATIONS}

This study was a pharmacoeconomic study using data from a systematic literature review, and thus cannot be considered a complete analysis of cost-effectiveness but instead a study of cost-consequence. The study aims were to present the incremental cost-effectiveness ratios for each clinical and urodynamic parameter considered, leaving the reader to decide which outcome is most important in their particular situation.

It is also important to emphasize that it was impossible to obtain details regarding quality of life from the literature. This precluded the comparative study of other effectiveness parameters, such as years of life adjusted by quality, for the two alternative treatments from the perspective of one common denominator.

Another noteworthy point is that this study did not employ rates of discount of future benefits and costs. The scope of this study was restricted to the costs related to the acquisition of the two medications studied, and for this reason the average ANVISA published prices to consumers for 2009 was used.

In summary, this preliminary investigation paves the way for further research in this area. Broader studies should incorporate the results reported and could examine the incorporation of technologies, given the clear need for use of these drugs as part of the therapeutic arsenal for treatment of patients with chronic diseases such as NDO. The results of the present study should be interpreted with care for making health care decisions.

\section{FUNDING SOURCES}

National Council for Scientific and Technologic Development (Conselho Nacional de Desenvolvimento Científico e Tecnológico (CNPq)/DECIT/REBRATS).

\section{REFERENCES}

ASLAN, A.R.; KOGAN, B.A. Conservative management in neurogenic bladder dysfunction. Curr. Opin. Urol., v.12, n.6, p.473-477, 2002.

BENNETT, N.; O’LEARY, M.; PATEL, A.S.; XAVIER, M.; ERICKSON, J.R.; CHANCELLOR, M.B. Can higher doses of oxybutynin improve efficacy in neurogenic bladder? $\mathrm{J}$. Urol., v.171, n.2, p.749-751, 2004.

BROOKS, M.E.; BRAF, Z.F. Oxybutynin Chloride (Ditrophan) - clinical uses and limitations. Paraplegia, v.18, n.1, p.6468,1980 .

BRUSCHINI, H. Bexiga neurogênica. In: BENDHACK, D.A.; DAMIÃO, R. Orgs. Guia prático de urologia. Rio de Janeiro: Sociedade Brasileira de Urologia; São Paulo: BG Cultural, 1999. p.273-278. 
CARTWRIGHT, P.C.; COPLEN, D.E.; KOGAN, B.A.; VOLINN, W.; FINAN, E.; HOEL, G. Efficacy and safety of transdermal and oral oxybutynin in children with neurogenic detrusor overactivity. J. Urol., v.182, n.4, p.1548-1554, 2009.

CHANCELLOR, M.B.; ANDERSON, R.U.; BOONE, T.B. Pharmacotherapy for neurogenic detrusor overactivity. Am. J. Phys. Med. Rehabil., v.85, n.6, p.536-545, 2006.

C H R I S T O P H, F.; M O S C H K O W I T S C H, A .; KEMPKENSTEFFEN, C.; SCHOSTAK, M.; MILLER, K.; SCHRADER, M. Long-term efficacy of tolterodine and patient compliance in pediatric patients with neurogenic detrusor overactivity. Urol. Int., v.79, n.1, p.55-59, 2007.

DIOKNO, A.; INGBER, M. Oxybutynin in detrusor overactivity. Urol. Clin. North Am., v.33, n.4, p.439-445, 2006.

ELLSWORTH, P.I.; BORGSTEIN, N.G.; NIJMAN, R.J.M.; REDDY, P.P. Use of tolterodine in children with neurogenic detrusor overactivity: relationship between dose and urodynamic response. J. Urol., v.174, n.4, p.1647-1651, 2005 .

ETHANS, K.D.; NANCE, P.W.; BARD, R.J.; CASEY, A.R.; SCHRYVERS, O.I. Efficacy and safety of tolterodine in people with neurogenic detrusor overactivity. J. Spinal. Cord Med., v.27, n.3, p.214-218, 2004.

FADER, M.; GLICKMAN, S.; HAGGAR, V.; BARTON, R.; BROOKS, R.; MALONE-LEE, J. Intravesical atropine compared to oral oxybutynin for neurogenic detrusor overactivity: a double-blind, randomized crossover trial. $J$. Urol., v.177, n.1, p.208-213, 2007.

FERRARA, P.; D’ALEO, C.M.; TARQUINI, E.; SALVATORE, S.; SALVAGGIO, E. Side-effects of oral or intravesical oxybutynin chloride in children with spina bifida. BJU Int., v.87, n.7, p.674-678, 2001.

FIGUEIREDO, T.A. Componente de medicamentos de dispensação excepcional. Available at: $<$ http://www. ensp.fiocruz.br/portal-ensp/judicializacao/pdfs/338.pdf $>$. Accessed on: 22 Feb. 2011.

FRANCO, I.; HOROWITZ, M.; GRADY, R.; ADAMS, R.C.; DE JONG, T.P.; LINDERT, K.; ALBRECHT, D. Efficacy and safety of oxybutynin in children with detrusor hyperreflexia secondary to neurogenic bladder dysfunction. J. Urol., v.173, n.1, p.221-225, 2005.
GAJEWSKI, J.B.; AWAD, S.A. Oxybutynin versus propantheline in patients with multiple sclerosis and detrusor hyperreflexia. J. Urol., v.135, n.5, p.966-968, 1986.

GETSIOS, D.; CARO, J.J; ISHAK, K.J.; EL-HADI, W.; PAYNE, K. Canadian economic comparison of extendedrelease oxybutynin and immediate-release tolterodine in the treatment of overactive bladder. Clin. Ther., v.26, n.3, p.431-438, 2004.

GOESSL, C.; KNISPEL, H.H.; FIEDLER, U.; HÄRLE, B.; STEFFEN-WILKE, K.; MILLER, K. Urodynamic effects of oral oxybutynin chloride in children with myelomeningocele detrusor hyperreflexia. Urology, v.51, n.1, p.94-98, 1998 .

GOESSL, C.; SAUTER, T.; MICHAEL, T.; BERGÉ, B.; STAEHLER, M.; MILLER, K. Efficacy and tolerability of tolterodine in children with detrusor hyperreflexia. Urology, v.55, n.3, p.414-418, 2000.

HORSTMANN, M.; SCHAEFER, T.; AGUILAR, Y.; STENZL, A.; SIEVERT, K.D. Neurogenic bladder treatment by doubling the recommended antimuscarinic dosage. Neurourol. Urodyn., v.25, n.5, p.441-445, 2006.

KAWABE, K.; ABE, S.; KANDA, T.; TEI, K. Clinical reevaluation of the effect of oxybutynin chloride on uninhibited neurogenic and reflex neurogenic bladder. Urol. Int., v.41, n.1, p16-20, 1986.

KENELLY, M.J.; DEVOE, W.B. Overactive bladder: pharmacologic treatment in the neurogenic population. Rev. Urol., v.10, n.3, p.182-191, 2008.

LEE, J.G.; HONG, J.Y.; CHOO, M.-S.; KWON, H.Y.; CHUNG, D.Y.; LEE, K.S.; LEE, J.Y.; LEE, T. Tolterodine: As effective but better tolerated than oxybutynin in Asian patients with symptoms of overactive bladder. Int. J. Urol., v.9, n.5, p.247-252, 2002.

MADERSBACHER, H.; MÜRTZ, G.; ALLOUSSI, S.; DOMURATH, B.; HENNE, T.; KÖRNER, I.; NIEDEGGEN, A.; NOUNLA, J.; PANNEK, J.; SCHULTE-BAUKLOH, H.; SCHULTZ-LAMPEL, D.; BOCK, P.; STRUGALA, $\mathrm{G}$. Propiverine vs oxybutynin for treating neurogenic detrusor overactivity in children and adolescents: results of a multicentre observational cohort study. BJU Int., v.103, n.6, p.776-781, 2008. 
MADERSBACHER, H.; STÖHRER, M.; RICHTER, R.; BURGDÖRFER, H.; HACHEN, H.J.; MÜRTZ, G. Trospium chloride versus oxybutynin: a randomized, double-blind, multicentre trial in the treatment of detrusor hyper-reflexia. Br. J. Urol., v.75, n.4, p.452-456, 1995.

MAHANTA, K.; MEDHI, B.; KAUR, B.; NARASIMHAN, K.L. Comparative efficacy and safety of extended release and instant release tolterodine in children with neural tube defects having cystometric abnormalities. J. Pediatr. Urol., v.4, n.2, p.118-123, 2008.

MALONE-LEE, J.; SHAFFU, B.; ANAND, C.; POWELL, C. Tolterodine: superior tolerability than and comparable efficacy to oxybutynin in individuals 50 years old or older with overactive bladder: a randomized controlled trial. $J$ Urol., v.165, n.5, p.1452-1456, 2001.

MCGHAN, W.F. Cost effectiveness and quality of life considerations in the treatment of patients with overactive bladder. Am. J. Manag. Care, v.7, suppl.2, p.62-75, 2001.

PALMA, T. Aspectos práticos do tratamento farmacológico da bexiga hiperativa. Rev. Prática Hospitalar, v.9, n.54, p.58-61, 2007.

PANNEK, J.; DIEDERICHS, W.; BÖTEL, U. Urodynamically controlled management of spinal cord injury in children. Neurourol. Uradyn., v.16, n.4, p.285-292, 1997.

REDDY, P.P.; BORGSTEIN, N.G.; NIJMAN, R.J.M.; ELLSWORTH, P.I. Long-term efficacy and safety of tolterodine in children with neurogenic detrusor overactivity. J. Pediatr. Urol., v.4, n.6, p.428-433, 2008.
SECOLI, S.R.; PADILHA, K.G.; LITVOC, J.; MAEDA, S.T. Pharmacoeconomics: resultant perspective of decisions process. Ciênc. Saúde Coletiva, v.10, supl.0, p.287-296, 2005.

SOUZA, M.V.; KRUG, B.C.; PICON, P.D; SCHWARTZ, I.V.D. Medicamentos de alto custo para doenças raras no Brasil: o exemplo das doenças lisossômicas. Ciênc. Saúde Coletiva, v.15, suppl.3, p.3443-3454.

STÖHRER, M.; MÜRTZ, G.; KRAMER, G.; SCHNABEL, F.; ARNOLD, E.P.; WYNDAELE, J.J. Propiverine compared to oxybutynin in neurogenic detrusor overactivity - results of a randomized, double-blind, multicenter clinical study. Eur. Urol., v.51, n.1, p.235-242, 2007.

TANAGHO, E.A.; BELLA, A.J.; LUE, T.F. Urologia Geral de Smith. In: TANAGHO, E.A; MCANINCH, J.D. (Eds.). Distúrbios neuropáticos da bexiga. 17.ed. Porto Alegre: AMGH, 2010. cap.27, p.438-454.

VAN KERREBROECK, P.E.V.A.; AMARENCO, G.; THRÜROFF, J.W.; MADERSBACHER, H.G.; LOCK, M.T.W.T.; MESSELINK, E.J.; SOLER, J.M. Dose-ranging study of tolterodine in patients with detrusor hiperreflexia. Neurourol. Urodyn., v.17, n.5, p.499-512, 1998.

WOODWARD, S. Current management of neurogenic bladder in patients with MS. Br. J. Nurs., v.13, n.7, p.362-370, 2004.

YOUDIM, K.; KOGAN, B.A. Preliminary study of the safety and efficacy of extended-release oxybutynin in children. Urology, v.59, n.3, p.428-432, 2002.

Received for publication on $24^{\text {th }}$ April 2011 Accepted for publication on $09^{\text {th }}$ March 2012 